RASĀYAN J. Chem.

Vol. 13 | No. 1 |417 - 422| January - March | 2020 ISSN: 0974-1496 | e-ISSN: 0976-0083 | CODEN: RJCABP

\title{
BIOACTIVE METABOLITE FROM MARINE SPONGE- DERIVED FUNGUS Cochliobolus geniculatus WR12
}

\author{
D. Handayani ${ }^{1, *}$, R. A. Putri ${ }^{1}$, F. Ismed ${ }^{1}$, T. Hertiani ${ }^{2}$, N. P. Ariantari ${ }^{3,4}$ \\ and P. Proksch ${ }^{3}$ \\ ${ }^{1}$ Laboratory of Sumatran Biota/Faculty of Pharmacy, Andalas University, \\ Padang 25163, Indonesia \\ ${ }^{2}$ Faculty of Pharmacy, Gadjah Mada University, Sekip Utara, Yogyakarta 55281, Indonesia \\ ${ }^{3}$ Institut für Pharmazeutische Biologie und Biotechnologie, Heinrich-Heine-Universität \\ Düsseldorf, Universitätsstrasse 1, 40225 Düsseldorf, Germany \\ ${ }^{4}$ Department of Pharmacy, Faculty of Mathematics and Natural Sciences, Udayana University, \\ 80361 Bali, Indonesia \\ *E-mail: dianhandayani@phar.unand.ac.id
}

\begin{abstract}
This study aims to find bioactive metabolites from fungus, which was isolated from marine sponge Haliclona fascigera. The fungus was identified molecularly as C. geniculatus WR12. The isolation of the bioactive compound was achieved by column chromatography with step gradient polarity (SGP) method and purification by recrystallization. The structure was determined based on spectroscopic analyses (UV, IR, HR-MS, ${ }^{1} \mathrm{H}$ and ${ }^{13} \mathrm{C}$ NMR). The antibacterial activity of the compound was tested against Methicillin-Resistant Staphylococcus Aureus (MRSA) by using the agar diffusion method. The Cytotoxicity of the compound was tested on the cancer cell lines by using the microculture tetrazolium (MTT) assay. The results of this study were obtained a pure compound (1). The compound was identified as radicinin based on 1D and 2D NMR and HRESIMS data. This compound showed cytotoxic activity with $\mathrm{IC}_{50}$ values of $60.68,30.89$, and $87.89 \mu \mathrm{g} / \mathrm{mL}$ against WiDr, T47D, and Hela cell lines, respectively, but not toxic against Vero cell $\left(\mathrm{IC}_{50}\right.$ value of $\left.607.31 \mu \mathrm{g} / \mathrm{mL}\right)$. Radicinin showed higher cytotoxic activity against T47D cells $\left(\mathrm{IC}_{50}=25.01 \mathrm{ppm}\right)$ compared with doxorubicin $\left(\mathrm{IC}_{50}=33.49 \mathrm{ppm}\right)$. The result of the antibacterial activity of radicinin showed the minimum inhibitory concentration (MIC) of $125 \mu \mathrm{g} / \mathrm{disc}$ against MRSA. Based on these results, it can be concluded that radicinin could be considered as a potential candidate for future anticancer and anti-MRSA drug.

Keywords: Antibacterial Activity, Cochliobolus geniculatus, Cytotoxic Activity, Haliclona fascigera, Marine Sponge-derived fungi, Radicinin
\end{abstract}

(C) RASĀYAN. All rights reserved

\section{INTRODUCTION}

The ocean is a huge source of bioactive compounds. It covers more than $70 \%$ of Earth's surface with the highest biodiversity such as marine invertebrates, vertebrates, and microorganisms. ${ }^{1,2}$ Among these biodiversity, marine sponge is a potential source of the novel active compound. Approximately, 8000 species of marine sponge spread around the world and 830 species originate in Indonesia. ${ }^{3,4}$ Several studies have been reported that secondary metabolites of marine sponge have a promising source of biological activities such as antibacterial, antifungal, and anticancer. ${ }^{5-8}$

The production of secondary metabolites from sea sponges is very dependent on the number of these organisms which are very limited. Therefore, the use of symbiotic microorganisms that live in marine organisms is the solution to this problem. This is supported by several studies that found similar bioactive compounds from marine symbiotic microorganisms. ${ }^{9-11}$ For instance, Manzamine alkaloid isolated from a marine sponge, Acanthostrongylophora sp, was isolated from its symbiont (Micromonospora sp.) as the antimalarial, tuberculosis and HIV drug. ${ }^{12}$

Rasayan J. Chem., 13(1), 417-422(2020)

http://dx.doi.org/10.31788/RJC.2020.1315517

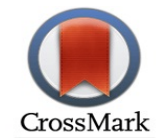




\section{RASĀYAN J. Chem. \\ Vol. 13 | No. 1 | 417 - 422| January - March | 2020}

In continuation of our previous research, we found ethyl acetate extract of $C$. geniculatus WR12, a marine sponge-derived fungus which was isolated from Haliclona fascigera, has potential effect as anticancer $\left(\mathrm{IC}_{50}=56.40 \mu \mathrm{g} / \mathrm{mL}\right)$ and antibacterial agent. ${ }^{13,14}$ This paper presents the isolation, structure determination, and bioactivity of isolated compound.

\section{EXPERIMENTAL}

\section{General Experimental Procedures}

A Perkin-Elmer Spectrum One FT-IR instrument used for the experimental IR spectrum. The ultraviolet spectrum was recorded on Shimadzu ${ }^{\circledR}$ ultraviolet-visible Pharmaspec 1700 spectrometer in wavelength of 200-800 nm. 1D and 2D NMR spectra were recorded on Bruker AVANCE DMX 600 and 300 NMR spectrometers. The chemical shifts were referred to residual solvent signals at $\delta_{\mathrm{H}} 2.50$ (DMSO- $\left.d_{6}\right) \mu \mathrm{g} / \mathrm{mL}$ for ${ }^{1} \mathrm{H}$ and $\delta_{\mathrm{C}} 39.5$ (DMSO- $d_{6}$ ) $\mu \mathrm{g} / \mathrm{mL}$ for ${ }^{13} \mathrm{C}$. Mass spectrum (ESI) was measured with a Finnigan LCQ Deca mass spectrometer and the HRESIMS spectrum was recorded with an FTHRMS-Orbitrap (ThermoFinnigan) mass spectrometer. The chromatographic silica gel 60 was provided by Merck ${ }^{\circledR}$. TLC analysis was performed on silica gel $60 \mathrm{~F}_{254 \mathrm{~nm}}\left(\mathrm{Merck}^{\circledR}\right)$. The lamp of $\mathrm{UV}_{\lambda 254 \mathrm{~nm}}$ and $\mathrm{UV}_{\lambda 365 \mathrm{~nm}}$ used as the visualization method on TLC analysis. Solvents were distilled prior to use, and spectrophotometric grade solvents were used for spectroscopic measurements.

\section{Fungal Strain}

The pure strain of $C$. geniculatus WR12 was collecting from the previous study. ${ }^{13}$ The fungus was stored at the Laboratory of Sumatran Biota, Faculty of Pharmacy, Andalas University, Padang, Indonesia.

\section{Molecular Identification of the Fungus}

The identification of marine-derived fungus (WR12) was done at the Institute of Science (LIPI), Cibinong, Indonesia with the molecular approach. The molecular identification was performed out using internal transcribed spacer (ITS) DNA barcode with special primer pairs for fungi, by following the procedures carried out by Saitoh, et al. (2006). ${ }^{15}$ The sequences were analyzed by the BLAST program on NCBI. MEGA 7.0 software is used to analyze phylogenetic trees created by the neighbor-joining tree method with a bootstrap value of 1000 replication. ${ }^{16}$

\section{Culture Conditions}

The fungus was grown in rice as media in which $100 \mathrm{~g}$ rice in Erlenmeyer was mixed with $110 \mathrm{ml}$ distilled water then the mixture was sterilized in an autoclave $\left(121^{\circ} \mathrm{C}, 15 \mathrm{lbs}, 15 \text { minutes }\right)^{13}$. This media was incubated at room temperature $\left(25^{\circ} \mathrm{C}\right)$ for four weeks. Fungi culture media $(100 \mathrm{~g})$ was extracted with ethyl acetate $(3 \times 100 \mathrm{ml})$. Ethyl acetate extract was separated from the culture medium by the funnel and perform three repetitions, and then was evaporated in vacuo with a rotary evaporator to give ethyl acetate crude extract $(5.5 \mathrm{~g})$.

\section{Isolation of Secondary Metabolites}

Ethyl acetate extract was purified by Sephadex LH20 column chromatography. The mobile phase of the column was methanol to obtain four fractions (F1, F2, F3, and F4). F2 was subjected to further silica gel chromatography, then eluted with $n$-hexane: ethyl acetate: methanol (1:3.5:0.5) to give eleven fractions. F2-6 was diluted with ethyl acetate and recrystallized with ethyl acetate and methanol to obtain compound $\mathbf{1}(126 \mathrm{mg})$.

\section{Characterization of Compound 1}

The compound was characterized by spectroscopic data (UV, IR, HR-MS, ${ }^{1} \mathrm{H}$ and ${ }^{13} \mathrm{C}$ NMR).

\section{Antibacterial Activity Testing}

Compound 1 was tested to human resistant pathogenic bacteria; MRSA and gentamicin ( $10 \mu 1 /$ disc $)$ were used as positive control by the agar disc diffusion method. ${ }^{17}$ Compound $\mathbf{1}$ was dissolved in DMSO with a concentration of $500 ; 250 ; 125 ; 62.5$ and $31.25 \mu \mathrm{g} /$ disc respectively. Antibacterial activity was detected after incubation for $24 \mathrm{~h}$ at $30{ }^{\circ} \mathrm{C}$. The existence of the clear zone of inhibition in the media was 
RASĀYAN J. Chem.

Vol. 13 | No. 1 | 417 - 422| January - March | 2020

considered as an indicator for antibacterial activity. The lowest concentration contained a clear zone around the paper disc was described as a minimum inhibitory concentration (MIC) value. ${ }^{18}$

\section{MTT Assay}

MTT assay was carried out with procedure experimental in Handayani et al. (2018). Four cell lines, HeLa as cervix cell line, WiDr as colon adenocarcinoma cell line, T47D as human ductal breast epithelial tumor cell line and Vero as normal cell line have been used for the assay. ${ }^{13,19}$ Compound 1 was made in several concentrations which are $300,150,75,37.5,18.75$ and $9.375 \mu \mathrm{g} / \mathrm{mL}$. Doxorubicin as a positive control was created in the concentration of $100,50,25,12.5$ and $6.25 \mu \mathrm{g} / \mathrm{mL}$.

\section{Statistical Methods}

Value Ln concentration is regressed against cell viability. Regression equations and probit analysis using SPSS were used to calculate $\mathrm{IC}_{50}$ values.

\section{RESULTS AND DISCUSSION}

The strain WR12 (Contig LPB 051 HF12) was identified as Cochliobolus geniculatus by using sequence analysis of the partial 18S rRNA gene. The nucleotide was compared to nucleotide BLAST of the gene bank database (NCBI GenBank) and recovered JN941617 Cochliobolus geniculatus (99\%) as the closest match to the rDNA of Contig LPB 051 HF12. The phylogenetic tree is shown in Fig.-1.
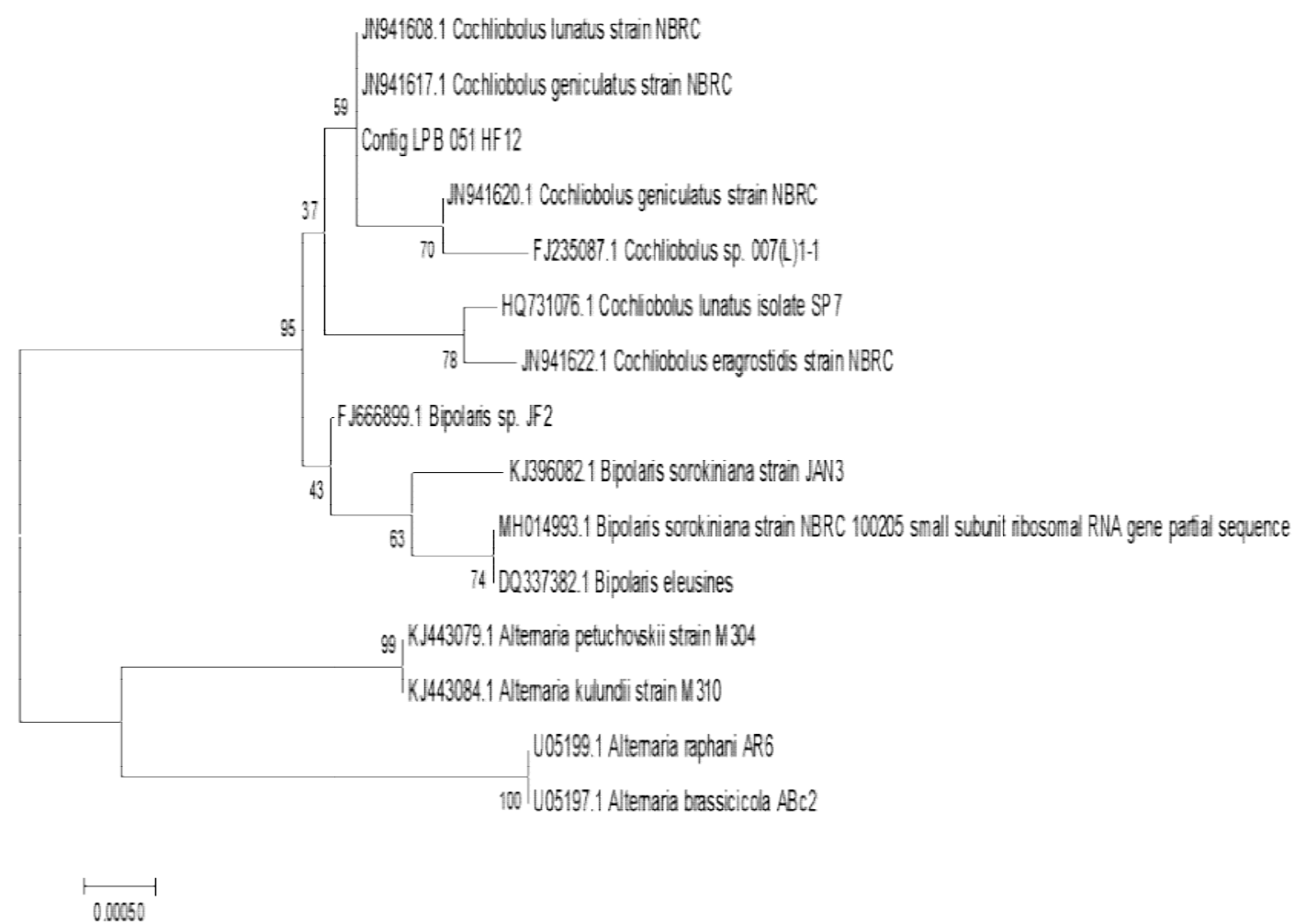

Fig.-1: The Phylogenetic Tree using the Neighbor-joining Method of 18S rRNA Gene Sequence from Some of the Fungi isolates Derived Haliclona fascigera and Some Strain of Cochliobolus, Bipolaris, and Alternaria. The Scale Bar indicates a 0.05 Substitution Nucleotide Position.

Several species of Cochliobolus are commonly isolated from the plant as an endophyte and epiphytic fungi. This genus is also found in association with a marine sponge and seagrasses. ${ }^{20}$ Based on microscopic morphology characterization, Cochliobolus colonies are grey to black, velvety or cottony. Mycelium consist of branched, septate, brown hyphae. The conidiophore cells usually curved or ellipse and almost always 4 -septate with the end cells almost colorless or very pale brown. ${ }^{21}$ 
RASĀYAN J. Chem.

Vol. 13 | No. 1 | 417 - 422 | January - March | 2020

Compound 1 compounds as a colorless needle crystal. The HRESIMS spectrum of $\mathbf{1}$ showed a prominent pseudo molecular ion peak at $m / z 237.0763[\mathrm{M}+\mathrm{H}]^{+}$, consistent with a molecular formula of $\mathrm{C}_{12} \mathrm{H}_{12} \mathrm{O}_{5}$. Its UV spectrum displayed the maximum wavelength at $221.60 \mathrm{~nm}(0.495)$ and $346.20 \mathrm{~nm}(0.481)$. The IR spectrum showed specific absorbance on $3325,2941,1658,1427$, and $1020 \mathrm{~cm}^{-1}$ hinted to the presence of hydroxide group, $\mathrm{C}-\mathrm{H}$ group, a carbonyl group, aromatic $\mathrm{C}=\mathrm{C}$ group, and $\mathrm{C}-\mathrm{O}$ group respectively. ${ }^{21}$ The ${ }^{1} \mathrm{H}$ spectrum (Table-1) showed resonances of two methyls and three olefinic protons, as well as two oxygenated protons. Detailed analysis of its 1D and 2D NMR spectra revealed that $\mathbf{1}$ is a known metabolite, radicinin (Fig.-2), previously reported from Nakajima et al., 1997 which was isolated from phytopathogenic fungi, Bipolaris coicis. ${ }^{23}$

Table-1: ${ }^{1} \mathrm{H}$ and ${ }^{13} \mathrm{C}$ NMR Spectroscopic Data of Compound $\mathbf{1}$ and Radicinin. ${ }^{22}$

\begin{tabular}{|c|c|c|c|c|}
\hline No. & $\begin{array}{l}\text { Compound } 1 \\
{ }^{13} \mathrm{C} \text { in DMSO } \\
(\delta \text { in } \mu \mathrm{g} / \mathrm{mL})\end{array}$ & $\begin{array}{c}\text { Radicinin }{ }^{13} \mathrm{C} \text { in } \\
\mathrm{CDCl}_{3 .}{ }^{21} \\
(\delta \text { in } \mu \mathrm{g} / \mathrm{mL})\end{array}$ & $\begin{array}{l}\text { Compound } 1{ }^{1} \mathrm{H} \text { in DMSO } \\
(\delta \text { in } \mu \mathrm{g} / \mathrm{mL}, \mathrm{J} \text { in } \mathrm{Hz})\end{array}$ & $\begin{array}{l}\text { Radicinin }{ }^{\mathrm{I}} \mathrm{H} \text { in } \mathrm{CDCl}_{3 .}{ }^{2 \mathrm{I}} \\
(\delta \text { in } \mu \mathrm{g} / \mathrm{mL}, \mathrm{J} \text { in } \mathrm{Hz})\end{array}$ \\
\hline 2 & 78.5 & 80.0 & $4.56(\mathrm{dq} 10.7,6.3,1 \mathrm{H})$ & $4.36(\mathrm{dq} 12.4,6.3,1 \mathrm{H})$ \\
\hline 3 & 71.8 & 72.0 & $3.97(\mathrm{dd} 10.8,5.2,1 \mathrm{H})$ & $3.98(\mathrm{~d} 12.4,1 \mathrm{H})$ \\
\hline 4 & 188.4 & 188.6 & - & - \\
\hline $4 a$ & 98.4 & 97.9 & - & - \\
\hline 5 & 156.3 & 156.7 & - & - \\
\hline 7 & 162.7 & 164.3 & - & - \\
\hline 8 & 99.5 & 98.0 & $5.87(\mathrm{~d} 5.2,1 \mathrm{H})$ & $5.84(\mathrm{~s}, 1 \mathrm{H})$ \\
\hline $8 \mathrm{a}$ & 174.9 & 176.3 & - & - \\
\hline 9 & 122.9 & 122.6 & $6.29(\mathrm{q} 1.6,1 \mathrm{H})$ & $6.03(\mathrm{dq} 15.5,1.8,1 \mathrm{H})$ \\
\hline 10 & 138.6 & 141.0 & $6.74(\mathrm{dq} 15.7,7.0,1 \mathrm{H})$ & $6.95(\mathrm{dq} 15.5,7.0,1 \mathrm{H})$ \\
\hline 11 & 18.4 & 18.8 & $1.92(\mathrm{dd} 7.0,1.7,3 \mathrm{H})$ & $1.95(\mathrm{dq} 7.0,1.8,3 \mathrm{H})$ \\
\hline 12 & 17.4 & 18.1 & $1.46(\mathrm{~d} 6.4,3 \mathrm{H})$ & $1.64(\mathrm{~d} 6.3,3 \mathrm{H})$ \\
\hline
\end{tabular}

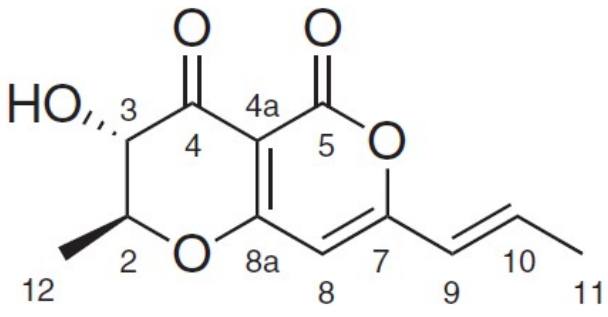

Fig.-2: Radicinin $(\mathbf{1})^{22}$

Radicinin (1) was first isolated from Stemphylium radicinin in 1953 and later observed from other plantassociated fungi, including Cochliobolus lunatus, Curvularia sp., and several members of the genus Alternaria. ${ }^{24-28}$ The structure was first reported in 1964 and confirmed by X-ray crystallography in $1982{ }^{29,30}$ This compound is known as a phytotoxic and antibacterial compound. ${ }^{30,31,32}$ Although little known about its activity against resistant bacteria, the mechanism of action was determined by a mechanism involving protease inactivation. ${ }^{31}$ Another potential bioactivity of radicinin (1) was an anticancer effect on several types of cancer cells. On our knowledge, no one has reported about its effect against cancer cells. Based on the previous study, which was reported in Handayani, et al., 2018, the biological activity of crude extract of $C$. geniculatus was active against cancer cells. This finding was continued to radicinin (1) carried out by MTT colorimetric. Krippendorff (2006) revealed that the cytotoxic compound can be categorized when its $\mathrm{IC}_{50}$ below $1000 \mu \mathrm{g} / \mathrm{mL} .^{33}$ Radicinin (1) showed extremely strong activity against T47D cell compared with doxorubicin while displayed lower activity against WiDr and HeLa. It showed less toxic on Vero normal cells. The $\mathrm{IC}_{50}$ is listed in Table-2. The degree of selectivity of Radicinin (1) shows for the cancer cell line can be expressed by its selectivity index (SI) value:

Selectivity Index $(\mathrm{SI})=\mathrm{IC}_{50}$ cancer cells $/ \mathrm{IC}_{50}$ Vero cells 
RASĀYAN J. Chem.

Vol. 13 | No. 1 |417 - 422| January - March | 2020

The higher the SI, the more promise an extract holds, due to its selectivity for Vero cells. ${ }^{34}$ Unfortunately, the SI of Radicinin (1) is below 2, it indicated that this compound is not selective on Vero cells.

Table-2: The $\mathrm{IC}_{50}$ Values of Compound $\mathbf{1}$ against the Cancer Cells (in $\mu \mathrm{g} / \mathrm{mL}$ )

\begin{tabular}{c|c|c|c|c|c|r|r}
\hline \multirow{2}{*}{ Compound } & \multicolumn{3}{|c|}{$\mathrm{IC}_{50}$ of Cancer and Normal Cell Line $(\mu \mathrm{g} / \mathrm{mL})$} & \multicolumn{3}{c}{$\begin{array}{c}\text { Selectivity Index } \\
\text { Cell Line / } \mathrm{IC}_{50} \text { of Cancer }\end{array}$} \\
\cline { 2 - 9 } & $\mathrm{WiDr}$ & $\mathrm{T} 47 \mathrm{D}$ & $\mathrm{HeLa}$ & Vero $^{\mathrm{a}}$ & $\mathrm{WiDr}$ & $\mathrm{T} 47 \mathrm{D}$ & $\mathrm{HeLa}$ \\
\hline 1 & 47.17 & 25.01 & 55.25 & 57.13 & 0.83 & 0.44 & 0.97 \\
\hline Doxorubicin $^{\mathrm{b}}$ & 15.12 & 33.49 & 19.21 & 8.63 & 1.75 & 3.88 & 2.23 \\
\hline
\end{tabular}

${ }^{\text {a }}$ Vero was normal cell line

${ }^{\mathrm{b}}$ Doxorubicin was a positive control

\section{CONCLUSION}

This study successfully demonstrated that the Cochliobolus geniculatus WR12, a marine-derived fungus, isolated from marine sponge Haliclona fascigera was a potential producer of anticancer and antibacterial agents. These findings add the expanding bodies of evidence that marine-derived fungi could be a big source for bioactive natural products. Based on these results, radicinin could be an interesting compound for further development as a lead anticancer and anti-MRSA drug.

\section{ACKNOWLEDGMENT}

The research was funded by the Directorate General of Higher Education, Ministry of National Education, Indonesia, with the contract number T/17/UN.16.17/PT.01.03/PD-KO/2019.

\section{REFERENCES}

1. T.O. Larsen, J. Smedsgaard, K. F. Nielsen, M.E. Hansen, J.C. Frisvad, Natural Product Report, 22(6), 672 (2005), DOI: 10.1039/b404943h

2. R. Osinga, E. Armstrong, J.G. Burgess, F. Hoffmann, J. Reitner, G. Schumann-Kindel, Hydrobiologia, 461, 55 (2001), DOI: 10.1023/A:1012717200362

3. J.N.A. Hooper, R.W.M. van Soest (Eds), 2002, In System Porifera: A Guide to the Classification of Sponges, New York, Kluwer/Plenum.

4. R.W.M. Van Soest, Netherlands Journal of Sea Research, 23, 2, 223 (1989).

5. E.D. de Silva, P.J. Scheuer. Tetrahedron Letters, 22(17),1611 (1980), DOI:10.1016/S00404039(00)77766-5

6. T.M. Zabriskieu, J.A. Klocke, C.M. Ireland, A.H. Marcus, T.F. Molinski, D.J. Faulkner, Journal of American Chemical Society, 108(11), 3123 (1986), DOI: 10.1021/ja00271a062

7. S.S. Ebada, V. Wray, N.J. de Voogd, Z. Deng, W. Lin, P. Proksch, Marine Drugs, 7(3), 435 (2009), DOI: $10.3390 / \mathrm{md} 7030435$

8. T. Wakimoto, A. Maruyama, S. Matsunaga, N. Fusetani, K. Shinoda, P.T. Murphy, Bioorganic \& Medicinal Chemistry Letters, 9(5), 727 (1999), DOI: 10.1016/S0960-894X(99)00059-1

9. P. Proksch, R. Ebel, R.A. Edrada, P. Schuup, W.H. Lin, Sudarsono, Pure and Applied Chemistry, 75(2), 343 (2003), DOI: 10.1351/pac200375020343

10. N. L. Thakur, W.E.G. Muller, Current Science, 86(11), 1506 (2004)

11. L. Zheng, H. Chen, X. Han, W. Lin, X. Yan, World Journal of Microbiology and Biotechnology, 21(2), 201 (2005), DOI:10.1007/s11274-004-3318-6

12. R.T. Hill, M. Hermann, O. Peraud, and N. Kasanah. Inventors: United States patent US 20050244938 Al: University of Maryland Biotechnology Institute, 2005.

13. D. Handayani, W. Rasyid, Rustini, E.N. Zainudin, T. Hertiani, Journal of Applied Pharmaceutical Science, 8(01), 055 (2018), DOI: 10.7324/JAPS.2018.8109

14. D. Handayani, R.F. Ahdinur, R. Rustini, Journal of Applied Pharmaceutical Science, 5(10), 154 (2015), DOI: $10.7324 / J A P S .2015 .501027$

15. K.I. Saitoh, K. Togashi, T. Arie, T. Teaoka, Journal of General Plant Pathology, 72(6), 348 (2006), DOI: $10.1007 / \mathrm{s} 10327-006-0300-1$ 
RASĀYAN $J$. Chem.

Vol. 13 | No. 1 |417 - 422| January - March | 2020

16. S. Kumar, G. Stecher, K. Tamura, Molecular Biology and Evolution, 33(7), 1870 (1996), DOI: 0.1093/molbev/msw054

17. A.W. Bauer, C. E. Roberts, W. M., J. R. Kirby, Antibiotics Annual, 7, 574 (1959)

18. M.A. Artasasta, Yanwirasti, M. Taher, A. Djamaan, D. Handayani, Rasayan Journal Chemistry, 12(3), 1463(2019), DOI: 10.31788/RJC.2019.1235284

19. P. Permanasari, T. Hertiani, A. Yuswanto, International Journal of Pharmaceutical and Clinical Research, 8(5), Suppl, 326 (2016)

20. D.S. Manamgoda, L. Cai, A.H. Bahkali, E. Chukeatirote, K.D. Hyde. Fungal Diversity, 51(3), 2011, DOI: $10.1007 / \mathrm{s} 13225-012-0189-2$

21. G.S. Hoog, Atlas of Clinical Fungi. Utrecht, CBS, 2000.

22. R. Silverstein, C, Fuson, D. Curtin, and T.C. Moril. The systematic identification of organic compound (Fourth Edition). Singapore, John Willey, and Sons, 1981.

23. H. Nakajima, T. Ishida, Y. Otsuka, T. Hamasaki, M. Ichinoe, Phytochemistry, 45(1), 41 (1997), DOI: $10.1016 / \mathrm{S} 0031-9422(96) 00804-7$

24. D. D, Clarke, F. F. Nord, Archives of Biochemistry and Biophysics, 45(2), 469 (1953), DOI: 10.1016/S0003-9861(53)80025-1

25. M. Nukina, S. Marumo, Tetrahedron Letter, 18(37), 3271 (1977), DOI:10.1016/S00404039(01)83215-9

26. S. Kadam, J. Poddig, P. Humphrey, J. Karwowski, M. Jackson, S. Tennent, The Journal of Antibiotic, 47(7), 836 (1994)

27. B.M. Pryor, R.L. Gilbertson, Mycologia, 94(1), 49 (2002), DOI:10.1080/15572536.2003.11833248

28. B. Tal, D.J. Robeson, B.A. Burke, A.J. Aasen, Phytochemistry, 24(4), 729 (1985), DOI: 10.1016/S0031-9422(00)84885-2

29. J.F. Groove. Journal of the Chemical Society, Chemical Communications, 3234 (1964)

30. D.J. Robeson, G.A. Strobel, Phytochemistry, 21(7), 1821 (1982), DOI:10.1016/S00319422(82)85081-4

31. T.J. Aldrich, E. Philippe, Rolshausen, C.M. Roper, J.M. Reader, M.J. Steinhaus, Phytochemistry, 116,130 (2015), DOI:10.1016/j.phytochem.2015.03.015

32. S. Li, M.W. Shao, Y.H. Lu, L.C. Kong, D.H. Jiang, Y.L. Zhang, Journal of Agricultural and Food Chemistry, 62(36), 8997 (2014), DOI:10.1021/jf502484n

33. B-F. Krippendorff, P. Lienau, A. Reichel, W. Huisinga, Journal of Biomolecular Screening, 12(1), 92 (2007), DOI: $10.1177 / 1087057106295897$

34. A. Koch, P. Tamez, J. Pezzuto, D. Soejarto, Journal of Ethnopharmacol, 101, 95 (2005), DOI: 10.1016/j.jep.2005.03.011

[RJC-5517/2019] 